Bangladesh J. Bot. 24(2): 251-259, 2015 (June)

\title{
IN VITRO EVALUATION OF FUNGICIDES AND PLANT EXTRACTS AGAINST PATHOGENIC FUNGI OF TWO RICE VARIETIES
}

\author{
Pranami Chowdhury ${ }^{1}$, MA Bashar and Shamim Shamsi* \\ Department of Botany, University of Dhaka, Dhaka-1000, Bangladesh
}

Key words: In vitro evaluation, Pathogenic fungi, Fungicides, Plant extracts, Rice varieties

\begin{abstract}
Five pathogenic fungi viz., Alternaria alternata (Fr.) Keissler, Curvularia lunata (Wakker) Boedijn, Drechslera oryzae Breda de Haan (Subramanian and Jain), Fusarium moniliforme Sheldon and Pestalotiopsis guepinii (Desm.) Stay. were isolated from two rice varieties viz., BRRI 29 (Boro) and Pajam (Aman) by Blotter and Tissue planting methods. Ten fungicides i.e. Bavistin $50 \mathrm{WP}$, Salcox $50 \mathrm{WP}$, Dithane M-45, Indofil M-45, Tall 25 EC, Ridomil MZ Gold, MC Sulphur 80, Greengel, Hayvit 80 WP and Capvit 50 WP at 100, 200, 300, 400 and 500 ppm were evaluated against the above mentioned five pathogenic fungi. Tall 25 EC completely inhibited the radial growth of the test fungi at all the concentrations except Fusarium moniliforme. Antifungal properties of ethanol extract of Artocarpus heterophyllus Lamk., Tagetes erecta L., Datura metel L., Senna alata (L.) Roxb., Azadirachta indica A. Juss., Citrus medica L., Mangifera indica L., Asparagus racemosus Willd., Nerium indicum Mill. and Allium sativum L. at 5, 10 and 20\% concentrations were evaluated against the five test pathogens. All the plant extracts completely inhibited the radial growth of the test fungi at $20 \%$ concentration except Asparagus racemosus.
\end{abstract}

\section{Introduction}

Rice is the staple food accounting for about 93 per cent of the total food produced about $70 \%$ of average calorie intake and 35\% of household expenditure (Abedin et al. 2012). Bangladesh is the fourth largest rice producer in the world (FAO 2010). The average world yield of rice is 3.84 tons/ha but the average yield of rice in Bangladesh is 2.52 tons/ha. Rice seeds act as the primary source of many fungal diseases. Grain spotting or discoloration is a complex malady in rice. It is an increasing problem in Bangladesh and elsewhere.

Annual loss of crops to world because of diseases has been estimated to be about 25000 million dollars; of this a major part is due to fungal pathogens. Recent studies revealed that more than $50 \%$ of the seed saved by farmers in Bangladesh are spotted or discolored (Mia 2004). Pathogens play an important role in deteriorating the quality and longevity of seed which cause germination failure, post emergence seedling infection and also seedling blight. Not enough information is available on the impact of farmers seed processing or management practices on the seed associated fungi (Akbar 1996).

A lot of researches have been done home and abroad on rice grain spotting and in its control but information on storages mycoflora of rice grain and its control is inadequate (Ganguly 1946, Pagmanaghan 1947, Neergaard 1977, Ou 1985 and Ahmed et al. 2013). So present research work has been undertaken to search the fungi associated with the rice grains with changed climate. The paper deals with management of pathogenic fungi associated with rice seeds.

\section{Materials and Methods}

The present study was based on spotted rice grains of two rice varieties, namely BRRI 29 and Pajam collected from farmers of Raiganj and Sirajganj (Rajshahi division), Gopalpur and Joydebpur (Dhaka division), Comilla and Laksmipur (Chittagong division), Rupatali and

*Author for correspondence: <prof.shamsi@gmail.com>. ${ }^{1}$ Directorate of Secondary and Higher Education Dhaka-1000, Bangladesh. 
Rahmatpur (Barisal division) during boro and aman seasons of 2012 and 2013. Samples were collected after harvesting and placed in clean brown paper bag labeled properly and preserved at $4^{0} \mathrm{C}$ in refrigerator for subsequent use.

The fungi were isolated from the samples following the "Tissue Planting method" on PDA medium (CAB 1968) and "Blotter method" of ISTA. Two hundred seeds of each sample were placed on three layers of moist blotting paper (Whatman No. 1) in Petri plates. The seeds were washed with sterile water and then surface sterilized by dipping in $10 \%$ Chlorox solution for 5 minutes. Seeds were placed in each plate and incubated at $25 \pm 2^{\circ} \mathrm{C}$ for 5 - 7 days.

Fungi grown in the seeds were transferred to separate PDA plates and PDA slants for further studies and preservation. The isolated fungi were identified based on morphological characteristics observed under a compound microscope following standard keys (Barnett and Hunter 1972, Booth 1971, Ellis 1971, 1976, Ellis and Ellis 1997 and Sutton 1980). Percentage of prevalence of fungi in different specimens was also recorded. Pathogenicity of the test fungi was done following seed inoculation technique (Reddy and Subbayya 1989).

For in vitro effect of plant parts extracts on the vegetative growth of test pathogens, ten plants viz., Artocarpus heterophyllus Lamk., Tagetes erecta L., Datura metel L., Senna alata (L.) Roxb., Azadirachta indica A. Juss., Citrus medica L., Mangifera indica L., Asparagus racemosus Willd., Nerium indicum Mill. and Allium sativum L. were selected. The desired parts of each plant were thoroughly washed in tap water, air dried and were prepared by crushing the known weight of fresh materials with ethanol in ratio of $(1: 1, \mathrm{w} / \mathrm{v})$. The mass of a plant part was squeezed through fine cloth and the extracts were centrifuged at $3000 \mathrm{rpm}$ for $20 \mathrm{~min}$. The supernatants were filtered through Whatman filter paper No.1 and the filtrate was collected in $250 \mathrm{ml}$ Erlenmeyer conical flasks. The requisite amount of the filtrate of each plant extract was mixed with PDA medium in which plant extracts were in 5, 10 and 20\% concentrations.

Ten fungicides viz., Bavistin 50WP, Tall 25EC, Ridomil MZ Gold, Dithane M-45, MC Sulphur 80 WP, Salcox 50WP, Indofil, Greengel, Hayvit 80 WP and Capvit 50 WP were collected from Krishi Upokoron Biponi Kendro, Khamarbari, Farmgate, Dhaka. For each fungicide, a stock solution having the concentration of $10000 \mathrm{ppm}$ was prepared. Then calculated amount of the stock solution of a fungicide was supplemented with sterilized PDA medium to get the final concentration of 100, 200, 300, 400 and 500 ppm etc. In the control set required amount of sterile water instead of fungicide solution was added to the PDA medium. Five mm mycelial agar disc cut from the margin of actively growing culture cut from the margin of actively growing culture of test fungi and then it was inoculated at the centre of the plate. Three replications were maintained in both the cases.

The radial growth of the colonies was measured at the 5th day of incubation. The per cent of growth inhibition of the test fungi was calculated by the formula described by Bashar and Rai (1991).

\section{Results and Discussion}

It was revealed that five pathogenic fungi were found associated with two rice varieties BRRI 29 and Pajam. Isolated fungi were Alternaria alternata (Fr.) Keissler, Curvularia lunata (Wakker) Boedijn, Drechslera oryzae Breda de Hann (Subramanian and Jain), Fusarium moniliforme Sheldon and Pestalotiopsis guepinii (Desm.) Stay.

Amongst the ten fungicides used in the present investigation, Bavistin, Dithane M-45 and Indofil were systemic while Sulphur, Tall and Salcox were protective fungicides. All the fungicides inhibited the radial growth of the pathogens but complete inhibition of the test pathogens were observed with Tall at all the concentrations used (Figs 1 - 5). 
On the radial growth of A. alternata, DithaneM-45, Indofil, Sulphur and Greengel were responsible for complete inhibition at 400 and $500 \mathrm{ppm}$ concentratios. Dithane M-45 also inhibited the radial growth completely at $300 \mathrm{ppm}$ whereas Greengel showed $83.33 \%$ and Bavistin showed $71.42 \%$ inhibition of growth. Salcox, Sulphur and Capvit showed $66.66 \%$ inhibition at 300 ppm, respectively (Fig. 1).

The complete inhibition of radial growth of $C$. lunata was observed with Dithane and Ridomil at $500 \mathrm{ppm}$. Bavistin, Greengel, Indofil and Salcox showed $80 \%$ inhibition at $500 \mathrm{ppm}$. Sulphur, Hayvit and Capvit showed 73.33, 82.85 and 73.33\% inhibition of growth at 500 ppm, respectively (Fig. 2).

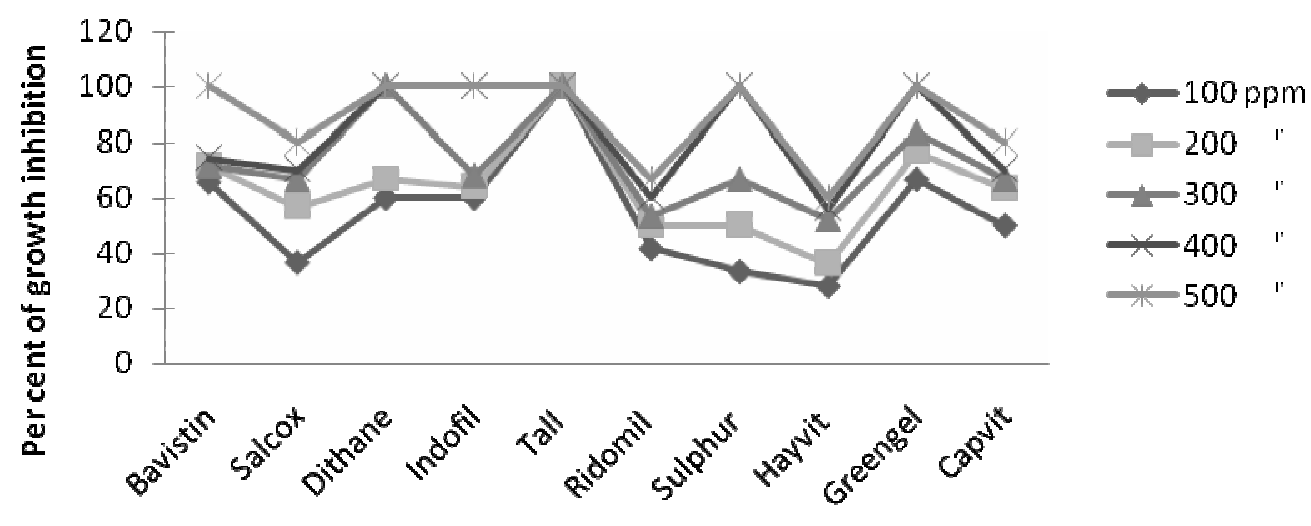

Fungicides

Fig. 1. Per cent inhibition of radial growth of Alternaria alternata owing to fungicides at different concentrations.

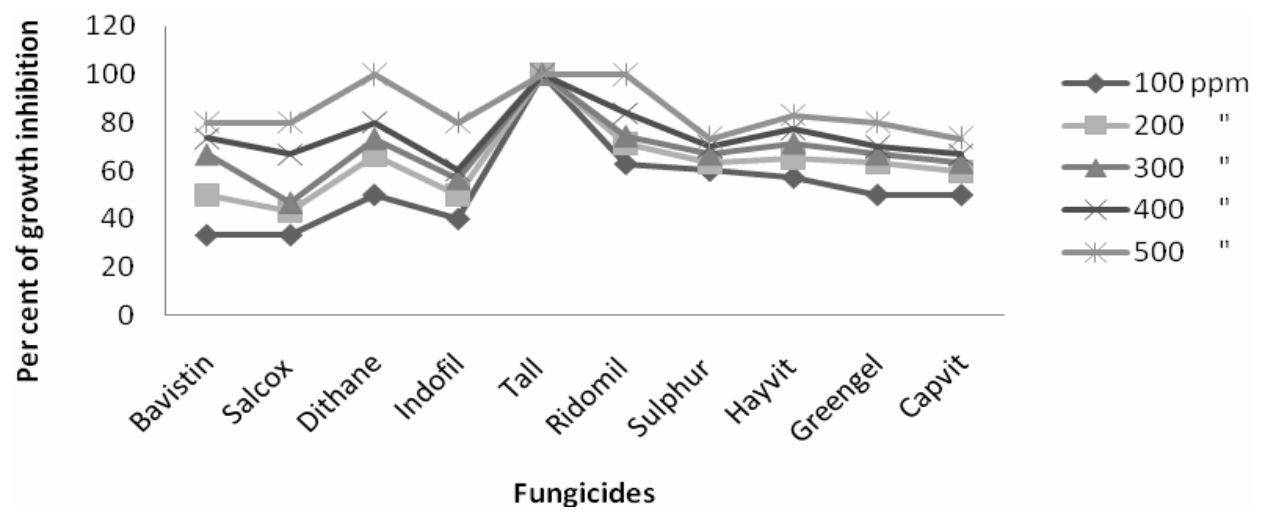

Fig. 2. Per cent inhibition of radial growth of Curvularia lunata owing to fungicides at different concentrations. 
The growth of $D$. oryzae was completely inhibited with Salcox, Indofil, Ridomil and Sulphur at 400 and 500 ppm. Bavistin, Dithane, Hayvit, Greengel and Capvit were also responsible for complete inhibition of radial growth at $500 \mathrm{ppm}$. They also showed 56, 80, 80, 84.62 and 66.66\% inhibition of growth at $400 \mathrm{ppm}$, respectively (Fig. 3).

The complete inhibition of radial growth of $F$. moniliforme was observed with Dithane, Ridomil and Sulphur at 300, 400 and $500 \mathrm{ppm}$. Bavistin also showed complete inhibition at 400 and $500 \mathrm{ppm}$. Capvit and Salcox showed complete inhibition at $500 \mathrm{ppm}, 71$ and $55 \%$ at $400 \mathrm{ppm}$, respectively. Indofil, Hayvit and Greengel recorded 65.5, 46.42 and 60\% inhibition of growth at 500 ppm, respectively (Fig. 4).

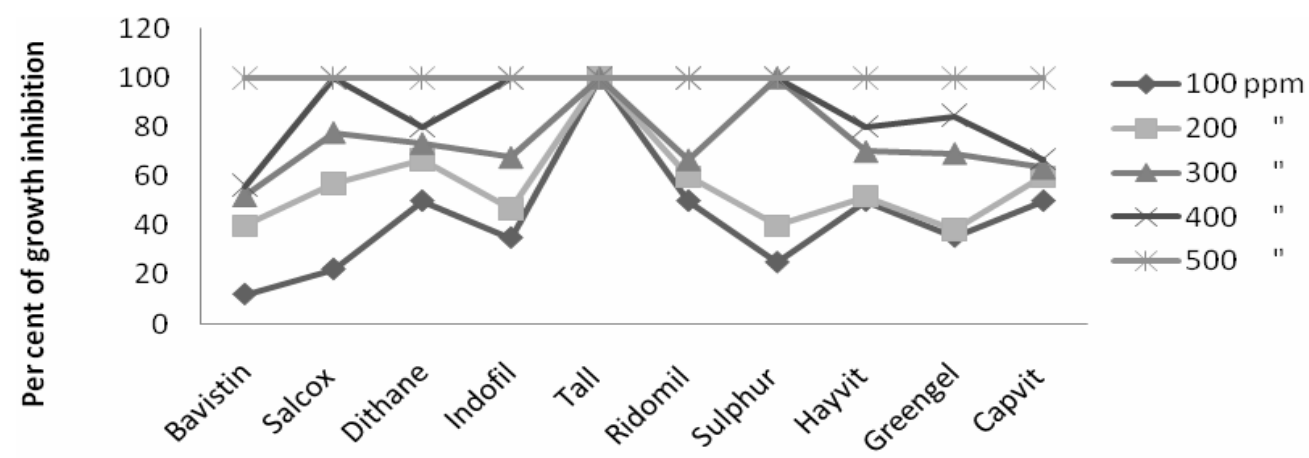

Fungicides

Fig. 3. Per cent inhibition of radial growth of Drechslera oryzae owing to fungicides at different concentrations.

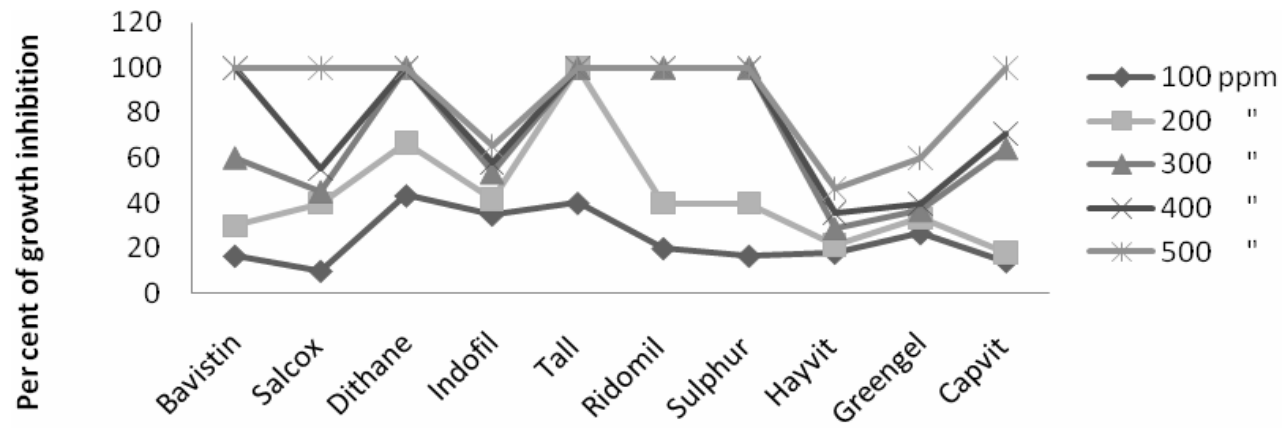

\section{Fungicides}

Fig. 4. Per cent inhibition of radial growth of Fusarium moniliforme owing to fungicides at different concentrations.

Indofil completely inhibited the radial growth of P. guepinii at 300, 400 and 500 ppm concentrations. Bavistin and Greengel also showed complete inhibition at 400 and $500 \mathrm{ppm}$. Ridomil and Sulphur showed 87.5\% inhibition, Salcox and Capvit showed 80\% inhibition of growth at $500 \mathrm{ppm}$. Dithane and Hayvit were responsible for 75 and $73.33 \%$ inhibition of growth, respectively at 500 ppm (Fig. 5). 
Amongst the ten fungicides, Tall showed best result and Hayvit showed least percentage of inhibition.

Farid et al. (2002) reported four fungicides viz. Bavistin, Hinosan, Tilt 250 EC and Dithane M-45 against Bipolaris oryzae. Dithane M- 45 was the best with $100 \%$ reduction of the prevalence of the pathogen and inhibited the mycelial growth at $0.3 \%$ of the seed weight as seed treatments and $500 \mathrm{ppm}$ as mycelial growth inhibition test followed by Tilt 250 EC, Hinosan and Bavistin. All the test fungicides were effective against Bipolaris oryzae at higher concentration (Farid et al. 2002).

Antifungal properties of ethanol extract of A. heterophyllus, T. erecta, D. metel, S. alata, A. indica, C. medica, M. indica, A. racemosus, N. indicum, A. sativum at 5, 10 and $20 \%$ concentrations were evaluated on 5 pathogenic fungi. All the plant extracts completely inhibited radial growth of the test fungi at 20\% concentration except A. racemosus (Figs 6 - 10).

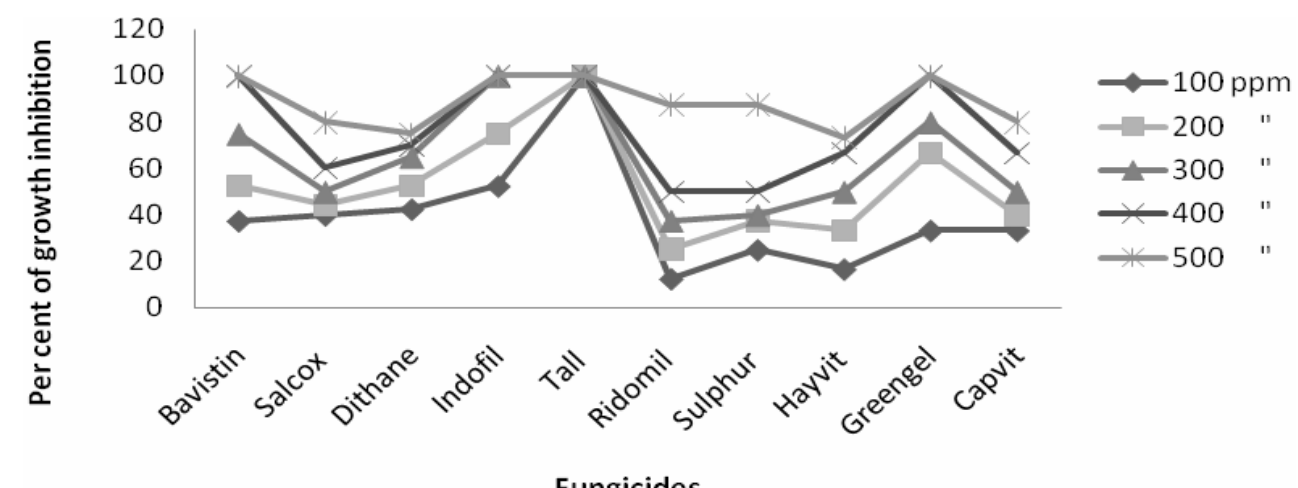

Fig. 5. Per cent inhibition of radial growth of Pestalotiopsis guepinii owing to fungicides at different concentrations.

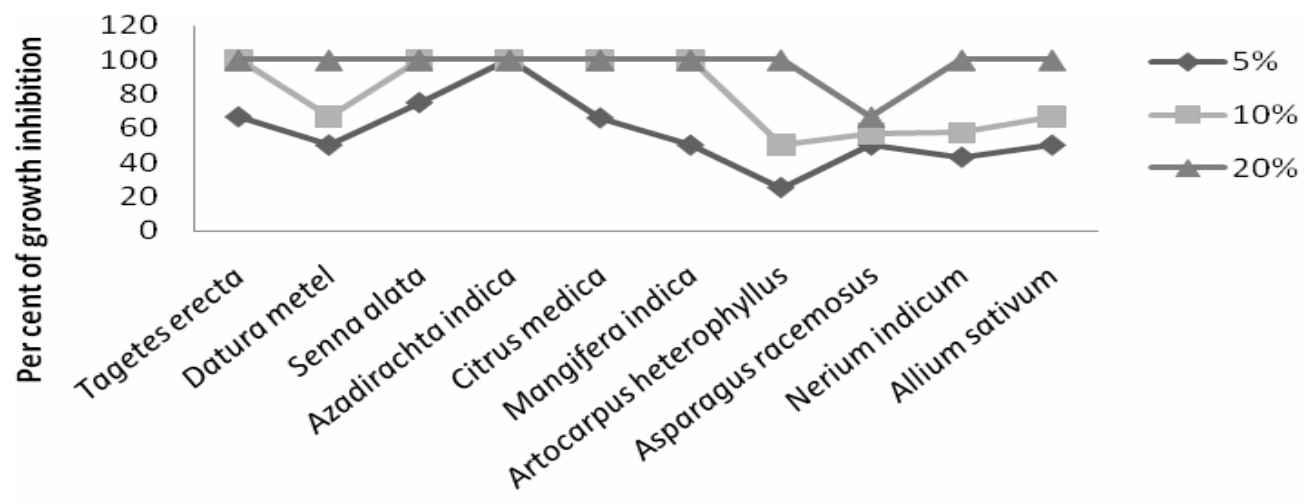

Plant Extracts

Fig. 6. Per cent inhibition of radial growth of Alternaria alternata owing to plant extracts at different concentrations. 
Ethanol extract of A. indica and C. medica at different concentrations also showed complete inhibition of radial growth of all pathogenic fungi. Only $5 \%$ concentration of $C$. medica showed $66 \%$ inhibition of vegetative growth of A. alternata. All the eight plants i.e. A. sativum, A. heterophyllus, A. racemosus, D. metel, M. indica, N. indicum, S. alata and T. erecta showed 50, $25,50,50,50,42.85,75$ and $66.66 \%$ inhibition of growth of A. alternata at 5\% concentration, respectively ( Fig. 6).

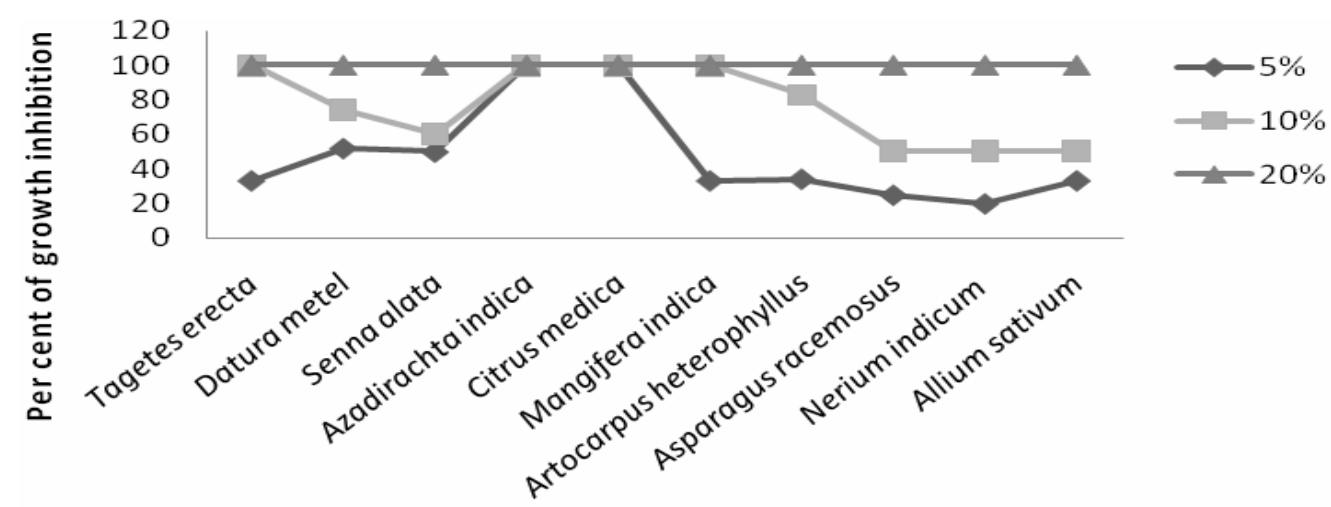

Plant Extracts

Fig. 7. Per cent inhibition of radial growth of Curvularia lunata owing to plant extracts at different concentrations.

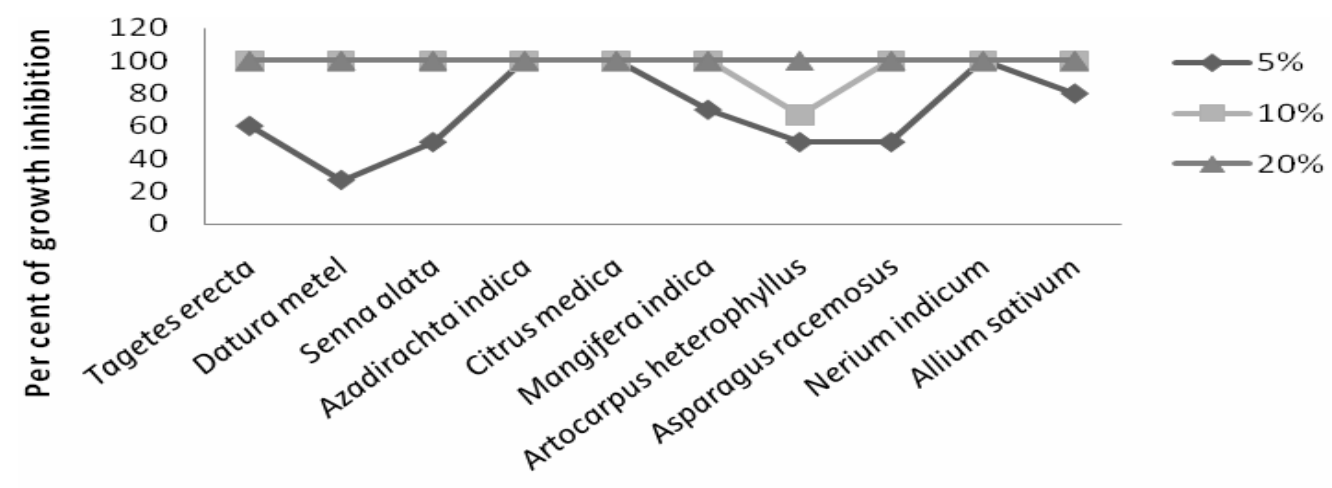

Plant Extracts

Fig. 8. Per cent inhibition of radial growth of Drechslera oryzae owing to plant extracts at different concentrations.

Ten per cent ethanol extract of $T$. erecta and $M$. indica were also responsible for complete inhibition of growth. Ten per cent ethanol extract of D. metel, S. alata, A. heterophyllus, A. racemosus, $N$. indicum and $A$. sativum showed 74, 60, 82.9, 50, 50 and 50\% inhibition of radial growth respectively. Ethanol extract of 8 plants i.e. A. sativum, A. heterophyllus, A. racemosus, $D$. metel, M. indica, N. indicum, S. alata and T. erecta showed 33.33, 34.28, 25, 52, 33.33, 20, 50 and $33.33 \%$ inhibition of radial growth of $C$. lunata at $5 \%$ concentration, respectively (Fig. 7). 
Ten and 20\% ethanol extract of all ten plants showed complete inhibition of radial growth of $D$. oryzae except $A$. heterophyllus which inhibited $66.66 \%$ growth at $10 \%$ concentration. Ethanol extract of $A$. indica, $C$. medica and $N$. indicum were also responsible for complete inhibition of radial growth at different concentrations. Five per cent ethanol extracts of seven plants namely $A$. sativum, A. heterophyllus, D. metel, M. indica, A. racemosus, S. alata and T. erecta were responsible for 80, 50, 26.66, 70, 50, 50 and 60\% inhibition of growth, respectively (Fig. 8).

Ten and 20\% ethanol extracts of all ten plants completely inhibited the radial growth of $F$. moniliforme. Azadirachta indica and C. medica also showed complete inhibition at 5\% concentration. Allium sativum, A. heterophyllus, A. racemosus, D. metel, M. indica, N. indicum, S. alata and $T$. erecta were also responsible for $48,40,50,33.33,60,50$ and $50 \%$ inhibition of radial growth, respectively at $5 \%$ concentration (Fig. 9).

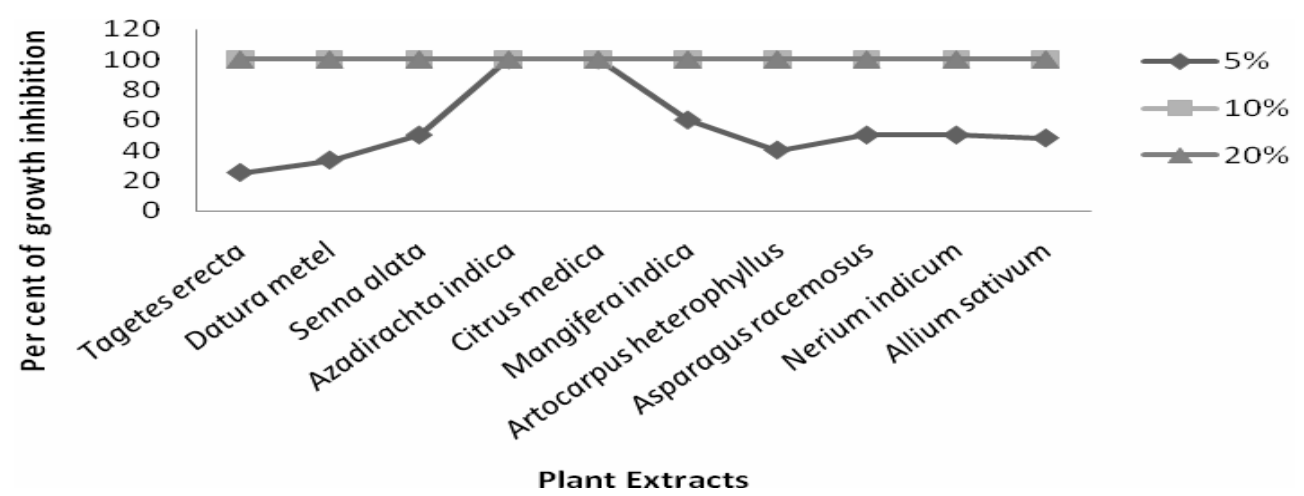

Fig. 9. Per cent inhibition of radial growth of Fusarium moniliforme owing to plant extracts at different concentrations.

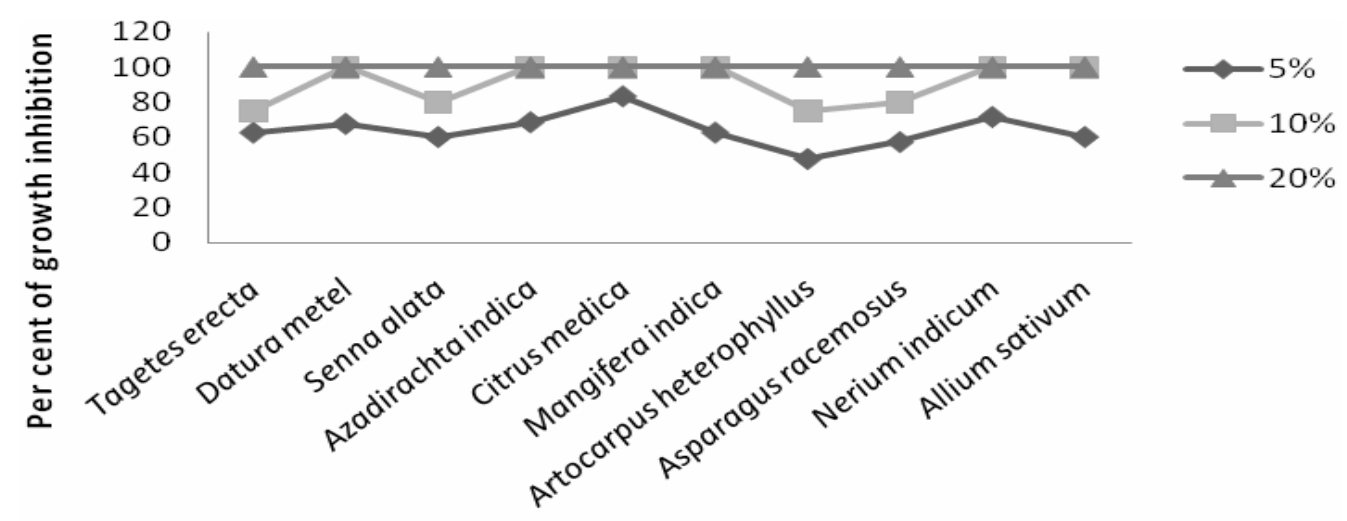

Plant Extracts

Fig. 10. Per cent inhibition of radial growth of Pestalotiopsis guepinii owing to plant extracts at different concentrations.

Ethanol extract of all the plants showed complete inhibition of radial growth of $P$. guepinii at $20 \%$ concentration. Ten per cent extract of A. sativum, A. indica, C. medica, $M$. indica, D. metel and $N$. indicum also showed $100 \%$ inhibition. Ten per cent ethanol extracts of S. alata, T. erecta, 
A. heterophyllus and A. racemosus were responsible for $80,75,75$ and $80 \%$ inhibition of growth, respectively. Five per cent ethanol extract of all the tested plants i.e. A. sativum, A. heterophyllus, A. racemosus, A. indica, C. medica, D. metel, $M$. indica, $N$. indicum, S. alata and T. erecta are also responsible for $60,47.5,57.12,68.42,83.15,67.5,62.5,71.42,60$ and $62.5 \%$ inhibition of growth, respectively (Fig. 10).

Mohana et al. (2011) from India reported that methanol extract of Acacia nilotica, Caesalpinia coriaria, Decalepis hamiltonii, Emblica officinalis, Lawsonia inermis and Mimosops elengi showed significant antifungal activity at $3500 \mu \mathrm{g} / \mathrm{ml}$ concentration on seed pathogens viz., Alternaria alternata, Aspergillus flavus, Curvularia lunata, Drechslera oryzae, D. halodes, Fusarium moniliforme, Pyricularia oryzae and Trichoconis padwickii by poisoned food technique.

Yeasmin et al. (2012) reported that seed borne fungi of rice were Bipolaris oryzae, Curvularia oryzae, Fusarium oxysporum, F. moniliforme, Nigrospora oryzae, Aspergillus flavus, A. niger and Penicillium sp., where prevalence of Bipolaris oryzae (7.5\%) and F. moniliforme (8.3\%) were the maximum. All the treatments significantly reduced the seed borne fungi up to $100 \%$ over the control, where Provax was found best and was significantly similar to garlic $(1: 1)$ extract against seed borne pathogens of rice. Mansur et al. also (2013) reported that garlic (1:1) extract was most effective in controlling seed borne fungi of rice.

The study revealed the presence of five pathogenic fungi viz., A. alternata, C. lunata, D. oryzae, $F$. moniliforme and $P$. guepinii associated with rice grains were completely controlled in vitro at different concentrations of Tall 25 EC. Subsequently antifungal properties of ethanol extracts of all the ten plants completely inhibited the radial growth of all the test fungi at $20 \%$ concentration.

\section{Acknowledgements}

The first author (PC) gratefully acknowledges to the University Grants Commission, Agargaon, Dhaka, Bangladesh for providing financial assistance to this research work in the form of a research fellowship.

\section{References}

Abedin MZ, Rahman MZ, Mia MIA and Rahman KMM 2012. In-store losses of rice and ways of reducing such losses at farmers' level: An assessment in selected regions of Bangladesh. J. Bangladesh Agril. Univ. 10(1): 133-144.

Ahmed M, Hossain M, Hassan K and Dash CK 2013. Effect of different plant extract on reducing seed borne infection and increasing germination of collected rice seed sample. Universal J. Plant Sci. 1(3): 66 -73.

Akbar A 1996. Effect of locations and cultivars of rice on the prevalent of fungi at pre and post harvest stages. An M. Sc. Ag. Thesis, Department of Plant Pathology, BAU, Mymensingh. pp. 66.

Barnett HL and Hunter BB 1972. Illustrated Genera of Imperfect Fungi. Burgess Pub. Co. Minneapolis, Minnesota. pp. 241.

Bashar MA and Rai B 1991. Antifungal activity of extracts of some plant parts against Fusarium oxysporum f. sp. ciceri. Bangladesh J. Bot. 20: 219 -222.

Booth C 1971. The Genus Fusarium. The Commonwealth Mycological Institute, Kew, England. pp. 221.

CAB 1968. Plant Pathologist's Pocket Book. The Commonwealth Mycological Institute, England. pp. 267.

Ellis MB 1971. Dematiaceous Hyphomycetes. The Commonwealth Mycological Institute, England. pp. 608.

Ellis MB 1976. More Dematiaceous Hyphomycetes. The Commonwealth Mycological Institute, England. pp. 507.

Ellis MB and Ellis JP 1997. Micro Fungi on Land Plants. An Identification Handbook. The Commonwealth Mycological Institute, England. pp. 868. 
Farid AKM, Khalequzzaman, Islam N, Anam MK and Islam MT 2002. Effect of fungicides against Bipolaris oryzae of rice under in vitro condition. Pak. J. Plant Pathol. 1(1): 4 -7.

FAO 2010. Food Outlook: Global Market Analysis; Global Information and Early Warning System, an internet version.

Ganguly D 1946. Helminthosporium disease in Bengal. Sci. and Cult. 112: 220-223.

Mansur A, Hossain M, Hassan K and Dash CK 2013. Efficacy of different plant extract on reducing seed borne infection and increasing germination of collected rice seed sample. Universal J. Plant Sci. 1(3): 66 $-73$

Mohana DC, Prasad P, Vijaykumar V and Raveesha KA 2011. Plant extract effect on seed borne pathogenic fungi from seeds of paddy grown in Southern India. J. Plant Protection Res. 51: 102-106

Mia MAT 2004. Production, drying and preservation of quality rice seeds at farmer level. In: Proceedings Technology Development Workshop. pp. 11-51. Organized by PETTA-IRRI and BRRI held in Bangladesh Rice Research Institute. Joydebpur, Gazipur, Dhaka.

Neergaard P 1977. Seed Pathology. A Halsted Press Book. Vol. 1.

Ou SH 1985. Rice Diseases. Commonwealth Mycological Institute, Kew, Surrey, England.

Pagmanaghan SY 1947. Occurrence of fungi inside rice kernels. Curr. Sci. 18: 442-443

Reddy KS and Subbayya J 1989. Evaluation of different method inoculation for screening rice cultivars for sheath rot resistance. (Eng.). Oryza 26(4): 416 -417.

Sutton BC 1980. The Coelomycetes. Fungi Imperfecti with Pycnidia, Acervuli and Stromata. Commonwealth Mycological Institute, England. pp. 696.

Yeasmin F, Ashrafuzzaman M and Hossain I 2012. Effects of garlic extract, Allamanda leaf extract and Provax-200 on seed borne fungi of rice. The Agriculturists 10(1): 46-50. 